\title{
Comparative Analysis of Teachers' Discipline and Control in Public and Private Secondary Schools in Lagos State, Nigeria
}

\author{
Olatunde Olaide Atanda ${ }^{\mathrm{a}}{ }^{*} \&$ Lydiah Wambugu ${ }^{\mathrm{b}}$ \\ ${ }^{a}$ Department of Business, Atlantic Hall School, Lagos, Nigeria \\ ${ }^{b}$ Department of Education Administration, Policy, \& Curriculum Studies, University of Nairobi, Kenya
}

\begin{abstract}
This paper examined the different approaches in teachers' discipline and control in public and private secondary schools in Lagos State, Nigeria. The population of this descriptive study were 3000 teachers drawn from all the six education districts of Lagos State. The sample consisted of 1200 teachers drawn using multistage sampling procedure. Descriptive and inferential statistics tools were used to analyse the data gathered. Descriptive statistical methods such as frequency counts and percentages were used to answer the research questions while an inferential statistic of T-test was employed to test the hypotheses at 0.05 alpha level of significance. The study revealed that approaches of teachers' discipline in public secondary schools are quite relaxed and easy from the approaches used in private secondary schools which are quite harsh. Also, the study revealed that the form of indiscipline among teachers in both public and private secondary schools in Lagos state are different. While the leaving the school before the closing time is mostly found in public schools, form of trading among teachers is the predominately form indiscipline in private secondary. The study recommended that teachers should strictly adhere to the school ethics as this will curb indiscipline in the school and also attend professional training, seminal or symposium to update their skills regularly.
\end{abstract}

Keywords: Teachers' discipline, teachers' control, public secondary schools, private secondary schools.

\section{Introduction}

Quality assurance in schools cannot be discussed without emphasising on the discipline and control of teachers. It has often been said that no institution can succeed beyond the level of its discipline. Generally, the discipline of school administrators, teachers and students has been a major herculean task in school management and administrations worldwide. The academic success or output of any school rests solely on the level of its discipline. In other words, no significant academic success can be achieved in an environment where there is disorderliness, display of mobocracy, lack of self-control, negligence of duty and noncompliance to the ethical standard of the school among teachers.

The rooting state of disciplinary challenges in the Nigerian three levels of school systems as assessed by (Ndu in Obi, 2004) stated that the level of violation of rules and regulations by teachers is astronomically high. This defilement includes breaching professional laid down rules, negligence of duty and one obligations, nonchalant attitude to professional responsibilities. In the view of (Peretomode, 2001), he laconically pointed out that the State Education Commission or Post Primary Schools Services Commission apart from being responsible for recruitment, placement, promotion, fixing and disbursing of remuneration of teachers is also charged with the overall disciplinary actions and controls of teachers in services. To further strengthening the grip, the Teachers Registration Council of Nigeria (TRCN) also set up a tribunal for trying erring teachers that go against the laid down professional conduct

Public secondary schools in Nigeria are schools managed, controlled and funded by the State Government. The adage of no one serves the government to the point of death has become the normal slang among public servants due to the soften management and control in government establishment, teachers in public secondary schools also take laws into their hand due to poor or no proper supervision of their professional conduct.

On the other hand, private secondary schools are set up by private individuals to primarily fill the gap created by public secondary schools due to their short comings such as embezzlement of funds, controversies in admission

\footnotetext{
* Corresponding author.

E-mail address: olaatanda3004@gmail.com (Olatunde Olaide Atanda)
} 
process, lack of adequate control and discipline of teachers etc (Atanda \& Olaifa, 2022). Unfortunately, private secondary schools that are supposed to revamp the standard of education have turned what is considered to the most important objective to the relegated goal and made profit making the priority at the expense of delivering quality education. According to (Atanda \& Olaifa, 2022) private secondary schools that have made profit their sole objective will not be ready to take arrant nonsense from any teacher that does not live to required expectation and thus must have high standard of disciplinary measure against any erring teachers

\subsection{Discipline and Control of Teachers}

The teachers service manual produced by the Federal Ministry of Education stated in article 5.2 that any teacher that flout any manual's code of conduct shall be exposed to varying degree of punishment by the school's management board in the case of Principal/Headmaster, and by the Principal/Headmaster and Schools Management Board in the case of teachers. The varying punishments is from sanctions to total dismissal depending on the severity of the wrongdoing. It is however accentuated that the principle of fair hearing is vital. In the case of teachers' misconduct, punishment to be given by the Principal/Headmaster shall take any form of;

1) Oral caution;

2) Written caution recorded in the log book;

3) Surcharge (for absenteeism from school or such dereliction of duty);

4) Adverse annual report;

5) Suspension from class with an immediate report to the relevant authority requesting ratification of the suspension and placement on half pay, pending appropriate action by authority.

Punishment by the Schools' Management Board may take the form of;

1) Written caution

2) Suspension on half pay (example; where court case is in progress)

3) Withholding of increment

4) Withdrawal of salary

5) Reduction in rank

6) Retirement

7) Dismissal

8) Removal of offender's name from the register of teachers.

But the question is this: even though both public and private secondary schools in Lagos State are monitored by the State Ministry of Education, are these punishments given to erring teachers accordingly? It is against this backdrop that this paper tries to look at the different measures teachers are disciplined in both public secondary schools and private secondary schools in Lagos State. Common violation of professional conducts and reprimands associated with such breaches are also discussed

\subsection{Quality assurance and indiscipline of teachers in schools}

Any school's efficiency is primarily the products of some factors such as quality of teachers, quality of students' admission criterial and ethical standards of the school. Managing teachers discipline as an input therefore needs an approach that will guarantee that other aspect of school environment are well coordinated for optimum output. Worries have been voiced by related stakeholders in the education sector about falling standard of education in Nigeria. Stakeholders are worried over the problems of dilapidated infrastructures, inadequate number of qualified teachers, inadequate and deteriorating physical facilities, as well as admitting unqualified students amongst others. In line with these concerns emanate the issue of quality assurance in secondary education for national transformation which is the baseline of the educational system. When these trepidations are assessed against the so called huge budgetary allocations by governments to education, concerns are expressed by stakeholders on the near absence of quality assurance in secondary schools for national transformation in the country.

Lack of disciplines in a school system by teachers can in no doubt affect the effective teaching and learning of the school. These indiscipline acts include been absent from work without permission, lateness to school or other official functions, failure to prepare lesson plan, inappropriate or lack of comment in students notes, collecting money from 
parent, aiding and abetting students to commit crimes in the school environment etc. When these acts permeate into the school systems, one begins to question the professionalism of teachers who are supposed to be iconic figures in moulding the future destiny of the country. This is because teachers are seen as demi-gods that have the creative power to make students transitioned from been dependent children to independent adults that will shape the development of the country.

\subsection{Concept of Discipline}

Different authors have come up with different definitions of discipline based on individual perspectives. Some authors define discipline as having self-control while some interchangeably use the word discipline with punishment. (Onyali, 2014) viewed discipline as the total effort in an academic environment aim at moulding or influencing a character into total obedience of a constituted authority. (Onyali, 2014) is of the opinion that transformation is a teaching process aimed at developing confident and trust in the recipients. For this purpose of study, I define discipline as doing as commanded by the relevant authority and not as convenient by teachers. It is a conscious and organized effort of complying to schools' order by teachers to ensure that teaching and learning objectives are achieved.

Discipline according to (Ezeugbor \& Eboatu, 2018), comprises of three main components:

1) Acting in accordance with orders such as military drilling

2) A type of regimented training that cultivates an enhanced skill,

3) Imposition of a reprimand with a view of correcting and training.

Discipline as seen by (Ezeugbor \& Eboatu, 2018), is a mode of control gained by demanding that instructions or commands are conformed with and punishment be given to erring teachers. In his work, (Ndu in Obi, 2004) opines that discipline is an act of training that improves the character of a person, orderliness, self-will and competence. Discipline is therefore seen as a conscious effort geared towards training and developing peoples character to follow an instituted order or an ethical standard as the practice of training people to obey rules or a code of behaviour, using punishment to correct disobedience.

Without any iota of doubt, discipline in any school is as a result of self-control, obedience to the rule of law, restraining oneself, forbearance and trustworthiness from teachers. A disciplined teacher is a teacher who is characterised with integrity, commitment, transparency, accountability, perseverance and prudency. A teacher that is disciplined is a teacher that is willing to deny self per time to achieve the institutional goal. It is the affirmation of self-control or self-will above mere cravings. This is synonymous to self-discipline. An educator that practices selfdiscipline has the capacity to resist behavioural temptations be it in the private or public with a determination of pressing forward to exhibiting what is right. It is therefore safe to conclude that defilement of disciplinary expectations of any school teachers will greatly affect teaching and learning of such school. This will consequently undermine the efforts of the school in realizing its goals and objectives

\section{Methodology}

The population of this descriptive study were 3000 teachers drawn from all the six education districts of Lagos State. The sample consisted of 1200 teachers drawn using multistage sampling procedure. The data for the study were gathered through the use of questionnaires tagged "Discipline of Teachers Questionnaire" (DTQ). To test the face and contents validity, the instrument was given to a senior colleague from a reputable university and the recommendations given were included in the final draft of the instrument. Moreover, the reliability of the instrument was determined through the test re-test method using Pearson Product Moment Correlation Co-efficient statistic and the correlation co-efficient value stood at 0.85 .

\subsection{Research Questions}

The following research questions have been formulated as guides in the conduct of the study:

1) What are the various approaches of teachers' discipline in public and private secondary schools in Lagos State?

2) What is the highest form of teachers' indiscipline in public and private secondary schools in Lagos State? 


\subsection{Research Hypotheses}

The following hypotheses were formulated for the purpose of this study

$\mathrm{H}_{1}$ : There is no significant difference in teachers' discipline in public and private secondary schools in Lagos State

$\mathrm{HO}_{2}$ : There is no significant difference in the highest form of teachers' indiscipline in public and private secondary schools in Lagos State

\section{Results and Discussion}

\subsection{Data Analysis}

Descriptive and inferential statistics tools were used to analyse the data gathered. Some descriptive statistical methods such as frequency counts and percentages were used to analyze the research questions. Also, an inferential statistic of T-test was employed to test the hypotheses at 0.05 alpha level of significance.

Table 1: Teachers' demographic details

\begin{tabular}{lllc}
\hline \multicolumn{2}{c}{ Teachers demographic details } & Total \\
\hline Gender & Male & Female & 1200 \\
& $780(65 \%)$ & $171(35 \%)$ & $(100 \%)$ \\
Teachers & Private secondary schools & & 1200 \\
& $600(50 \%)$ & Public secondary schools & $(100 \%)$ \\
\hline
\end{tabular}

Table 2: What are the various approaches of teachers' discipline in public secondary schools in Lagos State?

Public secondary schools in Lagos State

\begin{tabular}{|c|c|c|c|c|c|}
\hline & Variables & Often & Less often & Not often & Total \\
\hline 1 & How often does my school give oral caution? & $\begin{array}{c}1025 \\
(85.4 \%)\end{array}$ & $\begin{array}{c}105 \\
(8.8 \%)\end{array}$ & $\begin{array}{c}70 \\
(5.8 \%)\end{array}$ & $\begin{array}{c}1200 \\
(100 \%)\end{array}$ \\
\hline 2 & How often does my school give written caution? & $\begin{array}{c}20 \\
(1.7 \%)\end{array}$ & $\begin{array}{c}180 \\
(15 \%)\end{array}$ & $\begin{array}{c}1000 \\
(83.3 \%)\end{array}$ & $\begin{array}{c}1200 \\
(100 \%)\end{array}$ \\
\hline 3 & $\begin{array}{l}\text { How often does my school withhold teachers' } \\
\text { increment due to indiscipline? }\end{array}$ & $\begin{array}{c}6 \\
(0.5 \%)\end{array}$ & $\begin{array}{c}10 \\
(0.8 \%)\end{array}$ & $\begin{array}{c}1184 \\
(98.7 \%)\end{array}$ & $\begin{array}{c}1200 \\
(100 \%)\end{array}$ \\
\hline 4 & $\begin{array}{l}\text { How often does my school surcharge for } \\
\text { absenteeism without approval? }\end{array}$ & $\begin{array}{c}25 \\
(2.1 \%)\end{array}$ & $\begin{array}{c}35 \\
(2.9 \%)\end{array}$ & $\begin{array}{l}1140 \\
(95 \%)\end{array}$ & $\begin{array}{c}1200 \\
(100 \%)\end{array}$ \\
\hline 5 & $\begin{array}{l}\text { How often does my school surcharge for dereliction } \\
\text { of duty? }\end{array}$ & $\begin{array}{c}30 \\
(2.5 \%)\end{array}$ & $\begin{array}{c}40 \\
(3.3 \%)\end{array}$ & $\begin{array}{c}1130 \\
(94.2 \%)\end{array}$ & $\begin{array}{c}1200 \\
(100 \%)\end{array}$ \\
\hline 6 & $\begin{array}{l}\text { How often does my school suspend erring teachers } \\
\text { without warning? }\end{array}$ & $\begin{array}{c}13 \\
(1.1 \%)\end{array}$ & $\begin{array}{c}77 \\
(1.4 \%)\end{array}$ & $\begin{array}{c}1110 \\
(97.5 \%)\end{array}$ & $\begin{array}{c}1200 \\
(100 \%)\end{array}$ \\
\hline 7 & $\begin{array}{l}\text { How often does my school suspend erring teachers } \\
\text { after warning? }\end{array}$ & $\begin{array}{c}11 \\
(0.9 \%)\end{array}$ & $\begin{array}{c}29 \\
(2.4 \%)\end{array}$ & $\begin{array}{c}1160 \\
(96.7 \%)\end{array}$ & $\begin{array}{c}1200 \\
(100 \%)\end{array}$ \\
\hline
\end{tabular}


Public secondary schools in Lagos State

\begin{tabular}{|c|c|c|c|c|c|}
\hline & Variables & Often & Less often & Not often & Total \\
\hline 8 & How often does my school reduce teachers rank? & - & $\begin{array}{c}10 \\
(0.8 \%)\end{array}$ & $\begin{array}{c}1190 \\
(99.2 \%)\end{array}$ & $\begin{array}{c}1200 \\
(100 \%)\end{array}$ \\
\hline 9 & $\begin{array}{l}\text { How often does my school dismiss erring teachers } \\
\text { without warning? }\end{array}$ & $\begin{array}{l}25 \\
(2 \%)\end{array}$ & $\begin{array}{c}47 \\
(4 \%)\end{array}$ & $\begin{array}{l}1128 \\
(94 \%)\end{array}$ & $\begin{array}{c}1200 \\
(100 \%)\end{array}$ \\
\hline 10 & $\begin{array}{l}\text { How often does my school dismiss erring teachers } \\
\text { after warning? }\end{array}$ & $\begin{array}{c}25 \\
(2 \%)\end{array}$ & $\begin{array}{c}78 \\
(6.5 \%)\end{array}$ & $\begin{array}{c}1097 \\
(91.5 \%)\end{array}$ & $\begin{array}{c}1200 \\
(100 \%)\end{array}$ \\
\hline 11 & $\begin{array}{l}\text { How often does my school give fair hearing chance } \\
\text { to erring teachers? }\end{array}$ & $\begin{array}{c}100 \\
(8.3 \%)\end{array}$ & $\begin{array}{c}250 \\
(20.8 \%)\end{array}$ & $\begin{array}{c}850 \\
(70.9 \%)\end{array}$ & $\begin{array}{c}1200 \\
(100 \%)\end{array}$ \\
\hline 12 & $\begin{array}{l}\text { How often does my school suspend erring teachers } \\
\text { with pay as a tool of discipline? }\end{array}$ & $\begin{array}{c}84 \\
(7 \%)\end{array}$ & $\begin{array}{c}146 \\
(12 \%)\end{array}$ & $\begin{array}{l}970 \\
(81 \%)\end{array}$ & $\begin{array}{c}1200 \\
(100 \%)\end{array}$ \\
\hline 13 & $\begin{array}{l}\text { How often does my school suspend erring teachers } \\
\text { without pay as a tool of discipline? }\end{array}$ & $\begin{array}{c}24 \\
(2 \%)\end{array}$ & $\begin{array}{c}79 \\
(6.5 \%)\end{array}$ & $\begin{array}{c}1097 \\
(91.5 \%)\end{array}$ & $\begin{array}{c}1200 \\
(100 \%)\end{array}$ \\
\hline 14 & $\begin{array}{l}\text { How often does my school deny a teacher } \\
\text { promotion as a disciplinary measure? }\end{array}$ & $\begin{array}{c}5 \\
(0.4 \%)\end{array}$ & $\begin{array}{c}18 \\
(1.5 \%)\end{array}$ & $\begin{array}{c}1177 \\
(98.1 \%)\end{array}$ & $\begin{array}{c}1200 \\
(100 \%)\end{array}$ \\
\hline \multirow[t]{2}{*}{15} & $\begin{array}{l}\text { My school make erring teachers apologize to } \\
\text { students if found guilty }\end{array}$ & $\begin{array}{c}2 \\
(0.2 \%)\end{array}$ & $\begin{array}{c}56 \\
(4.7 \%)\end{array}$ & $\begin{array}{c}142 \\
(95.1 \%)\end{array}$ & $\begin{array}{c}1200 \\
(100 \%)\end{array}$ \\
\hline & Total & $\begin{array}{c}1395 \\
(7.7 \%)\end{array}$ & $\begin{array}{l}1160 \\
(6.4 \%)\end{array}$ & $\begin{array}{c}15445 \\
(\mathbf{8 5 . 9 \%})\end{array}$ & $\begin{array}{l}18000 \\
(100 \%)\end{array}$ \\
\hline
\end{tabular}

Source: Questionnaire

Table 3: What are the various approaches of teachers' discipline in private secondary schools in Lagos State?

\begin{tabular}{|c|c|c|c|c|c|}
\hline & & \multicolumn{4}{|c|}{ Private secondary schools in Lagos State } \\
\hline & Variables & Often & Less often & Not often & Total \\
\hline 1 & How often does my school give oral caution? & $\begin{array}{l}1057 \\
(88 \%\end{array}$ & $\begin{array}{c}87 \\
(7.3 \%\end{array}$ & $\begin{array}{c}56 \\
(4.7 \%\end{array}$ & $\begin{array}{l}1200 \\
(100 \%\end{array}$ \\
\hline 2 & How often does my school give written caution? & $\begin{array}{l}1038 \\
(86.5 \%\end{array}$ & $\begin{array}{l}84 \\
(7 \%\end{array}$ & $\begin{array}{l}78 \\
(6.5 \%\end{array}$ & $\begin{array}{l}1200 \\
(100 \%\end{array}$ \\
\hline 3 & $\begin{array}{l}\text { How often does my school withhold teachers' } \\
\text { increment due to indiscipline? }\end{array}$ & $\begin{array}{c}1071 \\
(89.2 \%\end{array}$ & $\begin{array}{c}71 \\
(5.9 \%\end{array}$ & $\begin{array}{c}58 \\
(4.9 \%\end{array}$ & $\begin{array}{l}1200 \\
(100 \%\end{array}$ \\
\hline 4 & $\begin{array}{l}\text { How often does my school surcharge for } \\
\text { absenteeism without approval? }\end{array}$ & $\begin{array}{l}1099 \\
(91.6 \%\end{array}$ & $\begin{array}{c}65 \\
(5.4 \%\end{array}$ & $\begin{array}{l}36 \\
(3 \%\end{array}$ & $\begin{array}{l}1200 \\
(100 \%\end{array}$ \\
\hline 5 & $\begin{array}{l}\text { How often does my school surcharge for } \\
\text { dereliction of duty? }\end{array}$ & $\begin{array}{c}1121 \\
(93.4 \%\end{array}$ & $\begin{array}{c}54 \\
(4.5 \%\end{array}$ & $\begin{array}{c}25 \\
(2.1 \%\end{array}$ & $\begin{array}{c}1200 \\
(100 \%]\end{array}$ \\
\hline 6 & $\begin{array}{l}\text { How often does my school suspend erring } \\
\text { teachers without warning? }\end{array}$ & $\begin{array}{c}1075 \\
(89.5 \%\end{array}$ & $\begin{array}{c}78 \\
(6.5 \%\end{array}$ & $\begin{array}{l}47 \\
(4 \%\end{array}$ & $\begin{array}{l}1200 \\
(100 \%]\end{array}$ \\
\hline 7 & $\begin{array}{l}\text { How often does my school suspend erring } \\
\text { teachers after warning? }\end{array}$ & $\begin{array}{c}1075 \\
(89.5 \%)\end{array}$ & $\begin{array}{c}69 \\
(5.8 \%)\end{array}$ & $\begin{array}{c}56 \\
(4.7 \%)\end{array}$ & $\begin{array}{c}1200 \\
(100 \%)\end{array}$ \\
\hline
\end{tabular}




\begin{tabular}{|c|c|c|c|c|c|}
\hline & \multirow[b]{2}{*}{ Variables } & \multicolumn{4}{|c|}{ Private secondary schools in Lagos State } \\
\hline & & Often & Less often & Not often & Total \\
\hline 8 & $\begin{array}{l}\text { How often does my school reduce teachers } \\
\text { rank? }\end{array}$ & $\begin{array}{c}1048 \\
(87.3 \%)\end{array}$ & $\begin{array}{c}98 \\
(8.2 \%)\end{array}$ & $\begin{array}{c}54 \\
(4.5 \%)\end{array}$ & $\begin{array}{c}1200 \\
(100 \%)\end{array}$ \\
\hline 9 & $\begin{array}{l}\text { How often does my school dismiss erring } \\
\text { teachers without warning? }\end{array}$ & $\begin{array}{c}1042 \\
(86.8 \%)\end{array}$ & $\begin{array}{c}84 \\
(7 \%)\end{array}$ & $\begin{array}{c}74 \\
(6.2 \%)\end{array}$ & $\begin{array}{c}1200 \\
(100 \%)\end{array}$ \\
\hline 10 & $\begin{array}{l}\text { How often does my school dismiss erring } \\
\text { teachers after warning? }\end{array}$ & $\begin{array}{c}1110 \\
(92.5 \%)\end{array}$ & $\begin{array}{c}65 \\
(5.4 \%)\end{array}$ & $\begin{array}{c}25 \\
(2.1 \%)\end{array}$ & $\begin{array}{c}1200 \\
(100 \%)\end{array}$ \\
\hline 11 & $\begin{array}{l}\text { How often does my school give fair hearing } \\
\text { chance to erring teachers? }\end{array}$ & $\begin{array}{c}1086 \\
(90.5 \%)\end{array}$ & $\begin{array}{c}25 \\
(2.1 \%)\end{array}$ & $\begin{array}{c}89 \\
(7.4 \%)\end{array}$ & $\begin{array}{c}1200 \\
(100 \%)\end{array}$ \\
\hline 12 & $\begin{array}{l}\text { How often does my school suspend erring } \\
\text { teachers with pay as a tool of discipline? }\end{array}$ & $\begin{array}{c}1095 \\
(91.2 \%)\end{array}$ & $\begin{array}{c}97 \\
(8.1 \%)\end{array}$ & $\begin{array}{c}8 \\
(0.7 \%)\end{array}$ & $\begin{array}{c}1200 \\
(100 \%)\end{array}$ \\
\hline 13 & $\begin{array}{l}\text { How often does my school suspend erring } \\
\text { teachers without pay as a tool of discipline? }\end{array}$ & $\begin{array}{c}1095 \\
(91.2 \%)\end{array}$ & $\begin{array}{c}47 \\
(4 \%)\end{array}$ & $\begin{array}{c}58 \\
(4.8 \%)\end{array}$ & $\begin{array}{c}1200 \\
(100 \%)\end{array}$ \\
\hline 14 & $\begin{array}{l}\text { How often does my school deny a teacher } \\
\text { promotion as a disciplinary measure? }\end{array}$ & $\begin{array}{c}1024 \\
(85.3 \%)\end{array}$ & $\begin{array}{c}78 \\
(6.5 \%)\end{array}$ & $\begin{array}{c}98 \\
(8.2 \%)\end{array}$ & $\begin{array}{c}1200 \\
(100 \%)\end{array}$ \\
\hline 15 & $\begin{array}{l}\text { My school make erring teachers apologies to } \\
\text { students if found guilty }\end{array}$ & $\begin{array}{c}1102 \\
(91.8 \%)\end{array}$ & $\begin{array}{c}87 \\
(7.2 \%)\end{array}$ & $\begin{array}{c}11 \\
(1 \%)\end{array}$ & $\begin{array}{c}1200 \\
(100 \%)\end{array}$ \\
\hline & Total respondents & $\begin{array}{c}16138 \\
(89.7 \%)\end{array}$ & $\begin{array}{l}1089 \\
(6 \%)\end{array}$ & $\begin{array}{c}773 \\
(4.3 \%) \\
\end{array}$ & $\begin{array}{l}18000 \\
100 \%)\end{array}$ \\
\hline
\end{tabular}

Source: Questionnaire

From the tables $2 \& 3$, it is factual that approaches of teachers' discipline in public secondary schools are quite different from the approaches used in private secondary schools in Lagos State. Summarily, all the different approaches are often use at $7.7 \%$ in public secondary schools compared to $89.7 \%$ rate in private secondary schools. Looking at some approaches, $83.3 \%$ in public secondary schools claimed that they do not get written caution when they misbehave while $86.5 \%$ in private secondary schools get written warning letter for their indiscipline acts. On absenteeism and dereliction of duty, $95 \%$ and $94.2 \%$ respectively claimed that they do not surcharge for this acts of indiscipline in public secondary schools while $91.6 \%$ and $93.4 \%$ in private secondary schools said they are surcharge for been absent without approval and when they leave their duty post respectively. Interestingly, fact shows that teachers are not demoted in public secondary schools when they misbehave while $87.3 \%$ teachers in private secondary schools said they can be demoted for behaving in an unethical manner. Erring teachers in public secondary schools are not often suspended with $96.7 \%$ claiming this while $89.5 \%$ in private secondary schools claimed that they risk suspension if they indulge in any act of indiscipline. In the same vein, $91.2 \%$ of private secondary schools said they get suspension without pay while $91.5 \%$ in public secondary schools said they don't get suspended without pay. The only approach synonymous in the form of discipline in both schools is the use of oral caution to erring teachers. Public secondary schools have $85.4 \%$ and private secondary schools have $88 \%$.

Table 4: What is the highest form of indiscipline among teachers in your school

\begin{tabular}{llcc}
\hline & Variables & $\begin{array}{c}\text { Public secondary } \\
\text { schools }\end{array}$ & $\begin{array}{c}\text { Private secondary } \\
\text { schools }\end{array}$ \\
\hline $1 \quad$ Flogging of students & 101 & 9 \\
& & $(8.4 \%)$ & $(0.8 \%)$ \\
$2 \quad$ Talking of alcohol or cigarette within the school premises & 24 & 14 \\
\end{tabular}




\begin{tabular}{|c|c|c|c|}
\hline & Variables & $\begin{array}{c}\text { Public secondary } \\
\text { schools }\end{array}$ & $\begin{array}{c}\text { Private secondary } \\
\text { schools }\end{array}$ \\
\hline 3 & Leaving school before the closing time & $\begin{array}{c}240 \\
(20 \%)\end{array}$ & $\begin{array}{c}49 \\
(4.1 \%)\end{array}$ \\
\hline 4 & Going late for lesson/Not going for lesson at all & $\begin{array}{c}101 \\
(8.4 \%)\end{array}$ & $\begin{array}{c}85 \\
(7.1 \%)\end{array}$ \\
\hline 5 & Collecting money from parents without remitting & $\begin{array}{c}78 \\
(6.5 \%)\end{array}$ & $\begin{array}{c}13 \\
(1.1 \%)\end{array}$ \\
\hline 6 & Coming late to school & $\begin{array}{c}199 \\
(16.6 \%)\end{array}$ & $\begin{array}{c}89 \\
(7.4 \%)\end{array}$ \\
\hline 7 & Not going to assembly & $\begin{array}{c}145 \\
(12.1 \%)\end{array}$ & $\begin{array}{c}254 \\
(21.2 \%)\end{array}$ \\
\hline 8 & Absent from school without approvals & $\begin{array}{c}109 \\
(9.1 \%)\end{array}$ & $\begin{array}{c}11 \\
(0.9 \%)\end{array}$ \\
\hline 9 & Forms of trading in the school & $\begin{array}{c}102 \\
(8.5 \%)\end{array}$ & $\begin{array}{c}489 \\
(40.6 \%)\end{array}$ \\
\hline 10 & Leaving a duty post & $\begin{array}{c}101 \\
(8.4 \%)\end{array}$ & $\begin{array}{c}189 \\
(15.8 \%)\end{array}$ \\
\hline & Total & $\begin{array}{l}1200 \\
(100 \%)\end{array}$ & $\begin{array}{l}1200 \\
(100 \%)\end{array}$ \\
\hline
\end{tabular}

Source: Questionnaire

Table 4 shows the highest form of indiscipline among teachers in both public and private secondary schools in Lagos state. From the table, it is evident that the three highest level of indiscipline according to his survey predominately witnessed in Lagos state public secondary schools are: leaving the school before the closing time with 240 respondents (20\%) asserting to this while coming late to school closely followed with $16.6 \%$ and not going to assembly is the third highest form of indiscipline with $12.1 \%$

On the other hand, form of trading among teachers in private secondary schools in Lagos state constitutes the highest custom of indiscipline with $40.6 \%$ while absconding from assembly and leaving the duty post are second and third acts of indiscipline with $21.2 \%$ and $15.8 \%$ respectively

\subsection{Hypotheses testing}

Two operational hypotheses were proposed in the course of the study and were tested using t-test at 0.05 level of significance. To test these hypotheses, responses from the questionnaire were coded on statistical coding sheets. These sets of data were then subjected to t-test using SPSS 20.0 window version and the outputs revealed thus:

H01: There is no significant difference in the various approaches of teachers' discipline in public and private secondary schools in Lagos State?

From table 5, it is revealed that the calculated t-value of 4.87 is greater than the critical t-value of 1.96 at 0.05 level of significant at 1200 degree of freedom. The implication of this result is that the null hypothesis which states that there is no significant difference in the various approaches of teachers' discipline in public and private secondary schools in Lagos State was rejected. Therefore, the alternative hypothesis that states there is significant difference in the various approaches of teachers' discipline in public and private secondary schools in Lagos State was accepted. While public secondary schools in Lagos State had the mean score of 12.9, private secondary schools in Lagos State had mean score of 17.1 which represent the gap between the two schools. 
Table 5: Results of t- test on the various approaches of teachers' discipline in public and private secondary schools in Lagos State

\begin{tabular}{lccccccc}
\hline \multicolumn{1}{c}{ Variables } & N & X & SD & df & t-cal & t-cri & Decision \\
\hline $\begin{array}{l}\text { Public } \\
\text { schools }\end{array}$ & 600 & 12.9 & 7.25 & 1200 & 4.87 & 1.96 & H0 Rejected \\
$\begin{array}{l}\text { Private } \\
\text { schools }\end{array}$ & 600 & 17.1 & 8.21 & & & & \\
\hline
\end{tabular}

$\mathrm{HO}_{2}$ : There is no significant difference in the highest form of teachers' indiscipline in public and private secondary schools in Lagos State?

Table 6: Results of t- test the highest form of teachers' indiscipline in public and private secondary schools in Lagos

\begin{tabular}{lccccccc}
\hline \multicolumn{1}{c}{ Variables } & $\mathbf{N}$ & $\mathbf{X}$ & SD & df & $\begin{array}{c}\text { Cal t- test } \\
\text { value }\end{array}$ & $\begin{array}{c}\text { Cri t-test } \\
\text { value }\end{array}$ & Decision \\
\hline $\begin{array}{l}\text { Public } \\
\text { schools }\end{array}$ & 600 & 14.9 & 9.54 & 1200 & 5.11 & 1.96 & H0 Rejected \\
$\begin{array}{l}\text { Private } \\
\text { schools }\end{array}$ & 600 & 18.8 & 10.43 & & & & \\
\hline
\end{tabular}

From table 6, it is revealed that the calculated t-value of 5.11 is greater than the critical $t$-value of 1.96 at 0.05 level of significant at 1200 degree of freedom. The implication of this result is that the null hypothesis which states that there is no significant difference in the highest form of teachers' indiscipline in public and private secondary schools in Lagos State was rejected. Therefore, the alternative hypothesis that states there is significant difference in the highest form of teachers' indiscipline in public and private secondary schools in Lagos State was accepted. While public secondary schools in Lagos State had the mean score of 14.9, private secondary schools in Lagos State had mean score of 18.8 which represent the gap between the two schools.

\subsection{Discussion of the hypotheses}

The result of T-test table 4 showed that there is a significant difference in the various approaches of teachers' discipline in public and private secondary schools in Lagos State. This implies that private secondary schools in Lagos State use firm hand of disciplinary measure against erring teachers. The result is no surprise at all because private schools are owned, managed and controlled by private individuals.

On a general note, researches have proved that private schools are rated higher than public school in terms of standard of quality education (Atanda \& Olaifa, 2022). Delivering quality education will certainly require standard operation with state of the art infrastructural facilities. This consequently lead to hike in tuition fee of these schools and the teachers in in this category of schools are expected to behave in a professional manner at their best and their ethical standard be a top notch. The school owners on the other hand are expected to manage their schools in a way that best practices are gotten from the teachers. The level of discipline in these schools is expected to be high as well as sanctions to any defaulting teachers.

It is very pertinent to state at this junction that not all private schools are established to raise the standard of education. Some are established for financial gain at the expense of quality. The owners of these mushroom private schools have turned what is supposed to be citadel of quality learning to a money making machine. This of course will make them put some stringent measures in place to make sure that money keeps coming in to the business.

Tutors are the centre point of attention in any institutional systems. This is because, no schools can be better than the quality of their teachers. According to (Paln and Bodunde, 1999), educators supposed to have behavioural character worthy of emulations by students in their care which however, it not the case in today's educational system. Teachers in public secondary schools lack sincerity and commitment to duty; lack respect for the constituted authority and as a result make administration of a school a tough task for the administrators. This personal view is justified by my experience when questionnaires were sent to a particular public school before the normal closing hour of the day; most teachers had left the school. The question that should be asked is that, what gave the teachers the gut to leave the 
premises before the official closing hour? However, things are conducted differently in private schools as permission to exit the school gate before the closing hour must pass through multi-layer of approvals from the superiors.

Another personal view on the wide gap between the disciplinary measure in private and public secondary schools is the fact that discipline in public schools in Lagos State takes time and it involves a lot of modalities between the school and the district of the school. On the other hand, punishment is instantaneous in private schools. This is another reason why the approach of discipline in public schools is not as rigorous as we have it in private secondary schools in Lagos State.

\section{Conclusion and Recommendations}

\subsection{Conclusion}

The most visible and challenging administrative headache in schools is indiscipline of teachers. This administrative cankerworm is often instigated by poor remuneration, lack of professional training, poor condition of service, embarrassment from parents, bad government policies and sometimes societies negative influence on teachers. Consequently, this damaging and degrading behaviour on the teachers has a direct effect on students resulting into apparent drop in the academic standard of the schools. This calls for a swift action to eliminating the barbaric action from teaching profession so as to reduce the learners' indiscipline for the betterment of education output and nation's development. There is a supposition that students' behaviour is tied to teachers' behaviour and therefore a well disciplinarian teacher would most likely begat disciplined students and vice versa

\subsection{Recommendations}

The following are the researcher's recommendations

1) Professionalism should be the watch word of every teacher. This should also be the basis of every teacher's behaviour

2) Teachers should strictly adhere to the school ethics as this will curb indiscipline in the school

3) Teacher should regularly attend professional training, seminal or symposium to update their skills

4) School leaders should be exemplary leaders to teacher in upholding discipline in the school environment

\section{References}

Alabi, F. O, (2017). Teachers' characteristics and disciplinary problems in public primary schools in South-West, Nigeria. Education \& Science Journal of Policy Review and Curriculum Development 7(1), 33-45

Atanda, O.O, \& Olaifa, S. A. (2022). Comparative study of quality assurance practices in unity schools and private secondary schools in Kwara And Oyo States, Nigeria. Daengku: Journal of Humanities and Social Sciences Innovation, 2(1), 19-27.https://jurnal.ahmar.id/index.php/daengku/article/view/680/463

Ezeugbor, C. O. (2014). The administrative process. In Glad O. Unachukwu and Pertua N. Okorji (Eds). Educational management: A skill building approach. pp 35-56. Nimo Rex Charles \& Patrick Limited.

Ezeugbor, C. O.,\& Eboatu, V. N. (2018). Discipline and control of teachers in school administration. UNIZIK Journal of Educational Management and Policy,2(1), 87-100. Retrieved from https://journals.unizik.edu.ng/index.php/ujoemp/article/view/572

Obi, E. (2004). Law and education management. Enugu; Empathy International.

Onyali, L. C. (2014). School discipline. In Glad O. Unachukwu \& Perpetua N. Okorji (Eds) Educational management: A skill building approach. pp.231-251., Nimo: Rex Charles \& Patrick limited.

Paln, D. Z. \& Bodunde, H. A. (1999). An overview of examination malpractices in Nigerian education system. In S. I. Okoli \& L. U.Ezeani Education in Nigeria: A critical analysis. Onitsha, Lincel publishers. 96-106.

Peretomode (2001). Education law; Principles, cases and materials on Schools. Owerri, International University Press. 
Teachers Registration Council of Nigeria (2005). Teachers code of conduct. Abuja; Teachers Registration Council of Nigeria.

Teachers Registration Council of Nigeria (2010). Professional standards for Nigerian teachers. Abuja; Teachers Registration Council of Nigeria. 